\title{
DIETARY BLACK CUMIN (Nizella sativa) SEED MEAL ON GROWTH AND MEAT YIELD PERFORMANCE OF BROILERS
}

\author{
M. S. Jahan ${ }^{* 1}$, M. Khairunnesa ${ }^{2}$, S. Afrin ${ }^{3}$ and M. S. Ali ${ }^{4}$ \\ Department of Poultry Science, Bangladesh Agricultural University, Mymensingh-2202, Bangladesh
}

\begin{abstract}
A total of 144 , day old as hatched Cobb-500 broilers were fed adlibitum basis on a diet with $0 \%, 0.5 \%, 1.0 \%$ and $1.5 \%$ of Black Cumin Seed Meal up to 35 days of age to compare the effect of BCSM as herbal growth promoters on growth performance, meat yield characteristics and profitability of broilers. The experimental diets consisted of broiler starter and broiler grower, which were fed from 0-16 and 17-35 days of age, respectively. Diets supplemented with $1.5 \%$ BCSM showed significant effect on live weight at 21,28 and 35 days of old in broilers in various groups as compared to that of control group. Better feed conversion (2.02) also noticed at $1.5 \%$ level of BCSM at early stage (14 days of old) of broilers. There was no significant difference $(P>0.05)$ among the average live weight, dressing yield, thigh meat, wing meat, heart, gizzard liver, at $0 \%, 0.5 \%, 1.0 \%$ and $1.5 \%$ level of BCSM diet. But difference found within breast meat, drumstick meat, abdominal fat and skin of broilers at $1.5 \%$ level of BCSM diet. It may be concluded that supplementation of BCSM at $1.5 \%$ had the highest significant effect $(P<0.01)$ on feed cost $\left(\mathrm{Tk} \mathrm{kg}^{-1} \mathrm{~b}\right)$, production cost $\left(\mathrm{Tk} \mathrm{kg}^{-1} \mathrm{~b}\right)$ and profit $\left(\mathrm{Tk} \mathrm{kg}^{-1} \mathrm{~b}\right.$ ) and lower mortality. So that 1.5\% BCSM in diets can be used for economic and efficient broiler production than $0.5 \%$ and $1.0 \%$ level.
\end{abstract}

Keywords: Black cumin, growth promoter, herbal, broiler.

\section{INTRODUCTION}

Poultry farming is one of the most successful and fast growing industry that provides high quality protein at economic price. However, tremendous improvement already recorded in broilers by genetic approaches and balancing of diet. Antibiotic

\footnotetext{
* Corresponding author email: camy bd@yahoo.com

${ }^{1}$ Scientific officer, Bangladesh Livestock Research Institute, Savar, Dhaka

${ }^{2}$ Lecturer, Dairy and Poultry Science Department, Bangabandhu Sheikh Mujibur Rahman Agricultural University, Gazipur-1706, Bangladesh

${ }^{3}$ Lecturer, Poultry Science Department, Bangladesh Agricultural University, Mymensingh-2202

${ }^{4}$ Professor, Poultry Science Department, Bangladesh Agricultural University, Mymensingh-2202.
} 
used in poultry production for more than 50 years to treat and prevent potential diseases. AGP were supposed to increase growth, improve gut health, better nutrient utilization and feed conversion (Visek, 1978). One potential problem is the increased resistance of pathogenic bacteria to the approved antibiotics used for growth promotion. The occurrence of AGP-associated resistant bacteria has lead to concerns of human health risks. Therefore, the use of antibiotic growth promoters (AGP) has been banned in many countries and these led to investigations of alternative feed additives in animal production. The demand of organic products that are alternatives of AGP should be safe and economic. Therefore, there is great interest in developing natural alternatives to AGP in order to maintain both broiler performance and health. Many biological trials of certain herbal products were conducted as growth promoter. Encouraging results were demonstrated in respect to growth, feed conversion, increased survivability, immunity and livability in poultry (Kumar, 1991). Herbal growth promoters also exerted therapeutic effects against liver damage (Ghosh, 1992). Natural medicinal products from herbs and spices have also been used as feed additives for poultry diet (Guo, 2003). Plant-derived products have proven to be less toxic, residue free and are accepted as ideal feed additives in poultry diet (Wang et al., 1998). Advances in chemistry and identification of plant compounds are effective in treating certain diseases and renewed the interest in herbal medicines. Black cumin (BC) belonging to Nigella sativza (NS) is an annual spicy herb native to Mediterranean regions. BC is used for medicinal purposes, as herb and pressed oil. $\mathrm{BC}$ is traditionally used for a variety of conditions and treatments related to respiratory health, stomach and intestinal health, kidney and liver functions, circulatory and immune system support and for general well being. Therefore, in the past many observations were made for testing various alternative substances suitable to replace AGPs in poultry diets. Herbal products are used as growth promoters in the poultry diet like BC (Ahmad, 2005 and Ihsan, 2003). Including 2.5 or 5.0\% BSC in the diets of broilers has no deleterious effects on their performance, immunity, serum biochemical constituents or haematological indices (Sohail et al., 2012). However, no study was conducted to evaluate the comparative as well as synergistic effects of BC seeds on broiler health and performance of different economic traits, related to heart and liver functions. Under prevailing conditions, the current study was designed to assess the effect of $\mathrm{BC}$ seeds on broiler performance and survivability at different inclusion level and economic use of $\mathrm{BC}$ in broiler.

\section{MATERIALS AND METHODS}

This study was carried out with 144 day old as hatched Cobb 500 broilers for a period of 35 days at Bangladesh Agricultural University (BAU) Poultry Farm, Mymensingh to find out the effect of dietary levels of black cumin seed meal (BCSM) on feed consumption, weight gain, FCR, mortality, cost of production of BCSM in diet formulation to maximize the performance of broilers. Day old broilers (Cobb 500) were purchased from a commercial hatchery "Nourish Poultry and 
Hatchery Ltd" of Shreepur, Gazipur and black cumin was purchased from local market, Mymensingh. A total of 144 day old broilers were randomly distributed to 4 dietary groups each having 4 replications. The treatment groups were having $0 \%$, $0.5 \%, 1 \%$ and $1.5 \%$ BCSM. There were 9 chicks in each replication.

Locally available ingredients were used to formulate ration for the broilers. The diets were prepared by hand mixing. All ingredients except BCSM were purchased from the local market of Mymensingh town. Major ingredients were thoroughly mixed at first and then micro-ingredients. The diets were prepared with 4 different levels of BCSM $(0 \%, 0.5 \%, 1 \%$ and $1.5 \%)$. Broilers were fed two diets, starter $(0-14$ days) and grower (15-35 days). Ration formulated according to the standard nutrient requirement of Cobb 500 individual strain recommended by BSTI. The nutrient percentage in prepared starter and grower ration were showed in the (Table 1).

The experimental rooms was properly cleaned and disinfected first by phenyl solution later with vircon S. After drying, the experimental house was divided into 16 equal sized pens, separated by bamboo materials and wire net partitions according to treatments and replications. Pen and wire net partitions were disinfected by phenyl solution after cleaning and washing.

The experiment was conducted in a gable type open sided tin-shed house. The proper management procedures were followed during experimental period and identical management practices were maintained. The house was partitioned into 16 pens using wire-net $(90 \mathrm{~cm}$ height) where a group of 9 broilers were randomly allocated to each pen. Floor space for each broiler was $900 \mathrm{~cm}^{2}$ for comfort ability of broilers during summer. One trough $(90 \mathrm{~cm} \times 11.5 \mathrm{~cm} \times 6 \mathrm{~cm})$ feeder and one pot drinker with a capacity of one litter were provided in each pen up to 35days. Feeders were cleaned every week and drinkers were cleaned every morning. Fresh clean drinking water was provided twice daily up to 35 days. Just after arrival, chicks were supplied with a solution containing glucose, electrolytes. Saw dust was used as litter at a depth of $5 \mathrm{~cm}$. After third week previous litter was replaced by new dry saw dust. Every two days interval litter was stirred to prevent ammonia gas and maggot formation. All of the experimental broilers were vaccinated against New Castle disease and Infectious Bursal Disease at the age of day $5^{\text {th }}$ and $12^{\text {th }}$ respectively. All the vaccines were administered as per recommendation of the manufacturer. Temperature was maintained at $30^{\circ} \mathrm{C}$ as brooding temperature which was decreased gradually in subsequent weeks @ $2.5^{\circ} \mathrm{C} /$ week until the broilers were adjusted to environmental temperature. Each pen was provided two electric bulbs (100wt). Broilers were exposed to 24 hours continuous light in first 7days. Strict bio-security measures were taken during the experimental period. Entrance of personnel was restricted. Before entrance, shoes were changed and feet were dipped in a footbath containing disinfectant solution (potassium permanganate) and the footbath was at the entrance point of the experimental house. No birds died during the entire experimental period. 
At the end of the experiment, 16 broilers; one broiler from each replicate groups weighing average of pen weight were selected to determine meat yield characteristics. To facilitate processing, all broilers' feed was withdrawn 12 hours prior to killing. After complete bleeding, the slaughtered broilers were immersed in water heated to $51-55^{\circ} \mathrm{C}$ for 120 seconds in order to loosen the feathers of the carcasses. Each broiler was slaughtered, bled, skulled, eviscerated, dressed and dissected by following standard method. The thigh, wing, heart, gizzard and liver breast, drumstick, abdominal fat, skin and viscera of each broiler were weighed individually by using electric balance very carefully.

\section{Parameters recorded}

During dressing the following parameters were recorded; live weight, blood weight, feather weight, head weight, dressed weight, abdominal fat, viscera weight, liver weight, drumstick weight, heart weight and skin weight. The following records were kept throughout the experimental period; body weight, body weight gain, feed consumption, feed conversion ratio (FCR), mortality, production cost and profitability, records of dressing yield and dressing percentage. Records were kept for each week.

\section{Statistical analysis}

Analysis of Variance (ANOVA) was performed to compare growth performance, profitability and meat yield parameters. A SAS system was used for analysis of all data and all significant and non-significant effects were identified by Ducan's Multiple Range Test.

\section{Live weight}

\section{RESULTS AND DISCUSSION}

Generally live weight s increased with the age of birds. (Table 2). Live weights of broiler were similar on levels of at 7, 14 days of age. However, significant differences appeared at 21,28 and $35(\mathrm{P}<0.05)$ days of age where live weight increased within linear pattern at the increasing level of dietary black cumin seed meal (BC). Ziad et al. (2008), Al-Homidan et al. and Osman (2002), Siddig and Abdelati (2001), AL-Beitawi and El-Ghousein (2008), Abu-Dieyeh and AbuDarwish (2008) supported that broilers fed on 1.5\% crushed black cumin had higher $(\mathrm{P}<0.05)$ live body weight and body weight gain in broiler diet. The improvement in weight gain of the broilers using $\mathrm{BC}$ in their diets may probably be due to the fact that ethyl ether extracts of BC. It inhibits growth of intestinal bacteria such as $S$. aureus and E. coli as reported by (Hanafy and Hatam, 1991). The improvement in weight gain of the broilers using BCSM in their diets may probably be for its antioxidant properties which act as natural growth promoter. 


\section{Feed intake}

There was no difference in feed intake at early stage. Feed intake normally decreased with the increasing level of BCSM in diet. But feed intake at 21 days of age was differed on different diets. Feed intake appeared to be slightly ( $\mathrm{P}>0.05)$ higher on diet with $1.5 \%$ BCSM at 21 days of age. This result is coinciding with the finding of Abbas and Ahmed (2010) who mentioned that, addition of 1or $2 \%$ ground black cumin to the broiler diet significantly $(\mathrm{P}<0.05)$ decreased feed intake. A similar result was obtained by Halle et al. (1999) who explained that the addition of essential oil from black cumin affected feed intake in broilers. The experiment was conducted when the temperature was high. It may be one of the reasons to vary in feed intake.

\section{Feed conversion}

Weekly feed conversion (FC) of broilers on $0.0,0.5,1.0$ and $1.5 \%$ dietary BCSM were more or less similar $(\mathrm{p}<0.05)$ except 14 days of age. Higher FC was obtained from $1.5 \%$ BCSM diet which partially coincided with Al-Homidan et al. (2002), AL-Beitawi and El-Ghousein (2008), Abu-Dieyeh and Abu-Darwish (2008) and Durrani et al., 2007. It was $(\mathrm{P}<0.05)$ better in comparison with $0,0.5$ and $1 \%$ BCSM at 14 days of age. The increase FC obtained in broilers impressed for the diet with increasing level of BCSM. Such relationship indicates that, BCSM may content some lypolytic agents in the diet.

\section{Meat yield characteristics}

Dietary BCSM did not affect the average live weight, dressing yield, thigh meat, wing meat, gizzard, head, heart, liver, and neck with different supplementation of BCSM based diet (Table 3). Highly significant $(\mathrm{P}<0.05)$ differences were obtained for the percentage of breast meat, drumstick meat, skin and abdominal fat at different diets. Breast meat, drumstick meat and skin percent of broilers almost increase in the diet in a linear fashion with the increase of BCSM. Abdominal fat also decreased with increasing level of BCSM. It was contradictory to Durrani et al. (2007) who noticed that birds fed on rations supplemented with black cumin revealed no significant $(\mathrm{P}>0.05)$ effect on abdominal fat. The present investigation was almost similar with the Abbas and Ahmed (2010), Siddig and Abdelati (2001); El-Bagir et al. (2006); Durrani et al. (2007) who found that the addition of $40 \mathrm{~g} \mathrm{~kg}^{-1}$ in black cumin to broiler ration resulted in increased weight of thigh and breast meat. The most significant differences are noticed $(\mathrm{P}>0.05)$ in abdominal fat percentage for the lypolytic effect of BCSM. Relatively higher breast and drumstick meat may have an effect in live weight gain attributed to slaughter weight.

\section{Production cost and profit}

Feed cost and total production cost per broiler and per kg broiler increased by $1.5 \%$ BCSM than control $(\mathrm{P}<0.01)$ (Table 4). Such pattern of increasing feed cost is almost in linear fashion with increasing different level of supplementation of BCSM. 
Profit per broiler was highest on $0.5 \%$ and $1.5 \%$ BCSM and declined almost in a linear fashion $(\mathrm{P}<0.05)$ between diets 1 and $1.5 \%$ differ from higher group. On the other hand, there was no difference $(\mathrm{P}>0.05)$ in cost per $\mathrm{kg}$ diet at different level of BCSM. However there was a tendency of increasing profit margin of using BCSM based diet in broiler. The experimented results for cost analysis coincided with Ahmad (2005) and Ihsan (2003). Ahmad (2005), who reported supplementation of $\mathrm{BCSM}$ at $0.5 \%$, was more beneficial and profitable in broiler production than $1.0 \%$ level. Ihsan (2003) also reported that the broilers fed diets with BCSM, fetched more profit than the rations without supplementation of this herbal growth promoter. Increase in the profit margin of the birds fed rations containing herbal growth promoters may be attributed to the better efficiency of feed utilization, which resulted in more growth and better feed conversion which ultimately leading to higher profit margin in the broilers reared on BCSM diets.

\section{Mortality}

Overall mortality was $1.25 \%$ which is lower than accepted limit of commercial broiler. Only one bird from control and one from 0.5\% dietary BCSM group died during the whole experimental period and no treatment related adverse effect was detected. Mortality was detected only from heart failure, which was frequently observed in rapid growing of broilers.

\section{CONCLUSION}

Based on the above findings, it has been concluded that black cumin seed meal can be included at $1.5 \%$ level in the broiler diet as natural growth promoter for broiler to improve feed conversion ratio, carcass yield and survivability.

\section{REFERENCES}

Abbas, T. E. and Ahmed, M. E. 2010. Black cumin for poultry feed. World's Poultry Science Journal, 23: 66-80

Abu-Dieyeh, Z. H. M. and Abu-Darwish, M. S. 2008. Effect of feeding powdered black cumin seeds (Nigella sativa L.) on growth performance of 4-8 week-old broilers. Journal of Animal and Veterinary Advances, 7: 286-290

Al-Betawi, N. and El-Ghousein, S. S. 2008. Effect of feeding different levels of Nigella sativa seeds (black cumin) on performance, blood constituents, and carcass characteristics of broiler chicks. International Journal of Poultry Science, 7: 715-721

Al-Homidan, A., Al-Qarawi, A. A., Al-Waily, S. A. and Adam, S. E. I. 2002. Response of broiler chicks to dietary Rhazya strica and Nigella sativa. British Poultry Science, 43: 291-296

Ahmad, S., 2005. Comparative efficiency of garlic, turmeric and kalongi as growth promoter in broiler. Department Poultry Sciences. University of Agriculture, Faisalabad, Pakistan 
Durrani, F. R., Chand, N., Zaka, K., Sultan, A., Khattak, F. M. and Durrani, Z. 2007. Effect of different levels of feed added black seed on the performance of broiler chicks. Pakistan Journal of Biological Science, 10: 4164-4167

El-Bagir, N. M., Hama, A. Y., Hamed, R. M., Rahim, A. G. A. and Beyenen, A. E. 2006. Lipid composition of egg yolk and serum in laying hens fed diets containing black cumin (Nigella sativa). International Journal of Poultry Science, 5: 574-578

Ghosh, T. K. 1992. Efficiency of liver herbal product on counteracting aflatoxin on broiler birds. Indian Poultry Review, 32: 33-34

Halle, I., Thomann, R. and Flachowsky, G. 1999. Effect of ethereal (essential) oil and oil seeds on the growth of broilers, Germany. 23: 469-472

Hanafy, M. S. and Hatem, M. E. 1991. Studies on the antimicrobial activity of Nigella sativa seeds (Black cumin). Journal of Ethopharmacol, 34: 275-278

Ihsan, K. 2003. Effect of different levels of kalongi ( $N$. sativa) seeds on the performance of broilers. M. Sc. (Hons.) Thesis, Department of Poultry Sciences, University of Agriculture, Faisalabad, Pakistan

Kumar, O. M. 1991. Effect of Liv-52 syrup on broiler performance in North Eastern Region. Indian Poultry Review, 31: 37-38

Sidding, R. M. and Abdelati, K. 2001. Effect of dietary vitamin A and Nigella sativa on broiler performance. Proceedings of the 10th International Conference of the Association of Institution for Tropical Veterinary Medicine Livestock, Community and Environment, Copenhagen, Denmark

Sohail, H. K., Jahanzeb, A., Ahsan U. H. and Ghulam, A. 2012. Black cumin seeds as phytogenic product in broiler diets and its effects on performance, blood constituents, immunity and caecal microbial population. Italian Journal of Animal Science, 11:438444

Visek, W. J. 1978. The mode of growth promotion by antibiotics. Journal of Animal Science, 46:1447-1469

Wang, R. D. and Bourne, S. 1998. Can 2000 years of herbal medicine history help us solve problems in the year 2000? Biotechnology in the Feed Industry: Proceedings of Alltech`s 14th Annual Symposium, Kentucky, USA. 22: 273-291

Ziad, H. M., Abu-Dieyeh, Mohammad, S. and Abu-Darwish. 2008. Effect of feeding powdered Black Cumin Seeds (Nigella sativa L.) on growth performance of 4-8 weekold broilers. Journal of Animal and Veterinary Advances, 7(3): 286 - 290 
Table 1. Nutrient percentage of starter and finisher diet

\begin{tabular}{|l|c|c|}
\hline \multicolumn{1}{|c|}{ Nutrients } & Starter diet & Grower diet \\
\hline Energy ME/Kcal & 3010 & 3130 \\
\hline CF\% & 10.50 & 10.50 \\
\hline CP\% & 20.80 & 19.50 \\
\hline Ca\% & 0.98 & 0.95 \\
\hline P (Av.)\% & 0.48 & 0.48 \\
\hline Arginine\% & 0.095 & 0.095 \\
\hline Lysine\% & 1.0 & 0.97 \\
\hline Meth.\% & 0.65 & 0.65 \\
\hline Meth.+Cys\% & 0.80 & 0.80 \\
\hline Tryptophan\% & 0.25 & 0.25 \\
\hline Sodium & 0.168 & 0.168 \\
\hline
\end{tabular}

Table 2. Effects of dietary levels of black cumin seed meal (BCSM); 0, 0.5, 1.0 and $1.5 \%$ on live weight, feed intake and feed conversion efficiency of broilers at different ages

\begin{tabular}{|c|c|c|c|c|c|c|}
\hline \multirow[t]{2}{*}{ Parameter } & \multirow{2}{*}{$\begin{array}{l}\text { Age } \\
\text { (days) }\end{array}$} & \multicolumn{4}{|c|}{ Dietary black cumin (\%) } & \multirow{2}{*}{$\begin{array}{c}\text { Level of } \\
\text { significan } \\
\text { ce }\end{array}$} \\
\hline & & $\mathbf{0}$ & 0.5 & 1.0 & 1.5 & \\
\hline \multirow[t]{6}{*}{$\begin{array}{l}\text { Live weight } \\
\qquad\left(\mathrm{g} \mathrm{kg}^{-1}\right)\end{array}$} & $\begin{array}{l}\text { Initial } \\
\text { weight }\end{array}$ & 41.50 & 42.25 & 42.50 & 41.50 & NS \\
\hline & 7 & 128.25 & 131.00 & 130.00 & 135.00 & NS \\
\hline & 14 & 277.50 & 303.00 & 303.75 & 318.25 & NS \\
\hline & 21 & $428.75^{\mathrm{c}}$ & $522.50^{\mathrm{b}}$ & $522.50^{\mathrm{b}}$ & $558.75^{\mathrm{a}}$ & $*$ \\
\hline & 28 & $662.00^{\mathrm{c}}$ & $746.00^{\mathrm{b}}$ & $759.00^{\mathrm{b}}$ & $800.00^{\mathrm{a}}$ & $*$ \\
\hline & 35 & $954.00^{c}$ & $1038.75^{\mathrm{b}}$ & $1070.00^{\mathrm{b}}$ & $1122.5^{\mathrm{a}}$ & $*$ \\
\hline \multirow{2}{*}{$\begin{array}{l}\text { Feed intake } \\
\quad\left(\mathrm{g} \mathrm{kg}^{-1}\right)\end{array}$} & 7 & 123.00 & 132.75 & 124.75 & 121.75 & NS \\
\hline & 14 & 237.50 & 229.00 & 227.25 & 212.75 & NS \\
\hline
\end{tabular}




\begin{tabular}{|c|l|l|l|l|l|l|}
\hline & 21 & $297.50^{\mathrm{b}}$ & $393.25^{\mathrm{a}}$ & $387.00^{\mathrm{a}}$ & $404.50^{\mathrm{a}}$ & $*$ \\
\cline { 2 - 7 } & 28 & 483.75 & 429.50 & 430.50 & 418.00 & NS \\
\cline { 2 - 7 } & 35 & 658.50 & 619.00 & 660.75 & 650.00 & NS \\
\hline $\begin{array}{c}\text { Feed } \\
\text { Conversion }\end{array}$ & 7 & 1.41 & 1.49 & 1.43 & 1.29 & NS \\
\cline { 2 - 7 } & 14 & $1.59^{\mathrm{b}}$ & $1.37^{\mathrm{ab}}$ & $1.32^{\mathrm{ab}}$ & $1.13^{\mathrm{a}}$ & $*$ \\
\cline { 2 - 7 } & 21 & 2.04 & 1.82 & 1.79 & 1.72 & NS \\
\cline { 2 - 7 } & 28 & 2.09 & 1.95 & 1.81 & 1.73 & NS \\
\cline { 2 - 7 } & 35 & 2.29 & 2.14 & 2.13 & 2.02 & NS \\
\hline
\end{tabular}

abc, mean values with dissimilar superscripts are significantly different; NS; *; $\mathrm{P}<0.05$.

Table 3. Effect of feeding BCSM diets to broilers on meat yield characteristics of broiler at different ages

\begin{tabular}{|c|c|c|c|c|c|}
\hline \multirow[t]{2}{*}{ Variable $(\%)$} & \multicolumn{4}{|c|}{ Dietary black cumin (\%) } & \multirow{2}{*}{$\begin{array}{c}\text { Level of } \\
\text { significance }\end{array}$} \\
\hline & $\mathbf{0}$ & 0.5 & 1.0 & 1.5 & \\
\hline $\begin{array}{l}\text { Live weight } \\
\text { (g/broiler) }\end{array}$ & 952.5 & 1026.25 & 1055.5 & 1107.5 & NS \\
\hline Dressing yield & 57.90 & 57.32 & 59.77 & 60.19 & NS \\
\hline Breast meat & $14.49^{\mathrm{b}}$ & $15.28^{\mathrm{ab}}$ & $15.73^{\mathrm{b}}$ & $16.12^{\mathrm{a}}$ & $*$ \\
\hline Thigh meat & 5.65 & 5.48 & 5.81 & 6.02 & NS \\
\hline Drumstick meat & $2.48^{\mathrm{b}}$ & $2.63^{\mathrm{b}}$ & $2.70^{\mathrm{ab}}$ & $2.88^{\mathrm{a}}$ & $*$ \\
\hline Wing meat & 1.88 & 1.56 & 1.96 & 1.77 & NS \\
\hline Abdominal fat & $1.58^{\mathrm{b}}$ & $1.12^{\mathrm{b}}$ & $1.08^{\mathrm{b}}$ & $0.94^{\mathrm{a}}$ & $*$ \\
\hline Gizzard & 1.88 & 1.80 & 1.94 & 1.89 & NS \\
\hline Head & 2.86 & 3.03 & 2.86 & 2.74 & NS \\
\hline Heart & 0.47 & 0.44 & 0.45 & 0.48 & NS \\
\hline Liver & 2.58 & 2.26 & 2.44 & 2.31 & NS \\
\hline Neck & 2.69 & 2.45 & 2.39 & 2.76 & NS \\
\hline Skin & $13.88^{\mathrm{b}}$ & $13.24^{\mathrm{ab}}$ & $12.33^{\mathrm{ab}}$ & $11.67^{\mathrm{a}}$ & $*$ \\
\hline
\end{tabular}

abc, mean values with dissimilar superscripts are significantly different; NS; *; P<0.05 
Table 4. Effects of dietary black cumin seed meal at $0,0.5,1.0$ and $1.5 \%$ on cost of production and profit of broilers

\begin{tabular}{|l|c|c|c|c|c|}
\hline \multirow{2}{*}{ Parameters } & \multicolumn{3}{|c|}{ Dietary black cumin (\%) } & \multirow{2}{*}{ Sig. } \\
\cline { 2 - 5 } & $\mathbf{0}$ & $\mathbf{0 . 5}$ & $\mathbf{1 . 0}$ & $\mathbf{1 . 5}$ & \\
\hline Feed cost (Tk kg ${ }^{-1}$ broiler) & $57.24^{\mathrm{ab}}$ & $62.94^{\mathrm{b}}$ & $66.83^{\mathrm{b}}$ & $73.55^{\mathrm{a}}$ & $* *$ \\
\hline $\begin{array}{l}\text { Production cost (Tk kg } \\
\text { broiler) }\end{array}$ & $132.60^{\mathrm{c}}$ & $145.00^{\mathrm{b}}$ & $151.40^{\mathrm{b}}$ & $162.20^{\mathrm{a}}$ & \multirow{2}{*}{$* *$} \\
\hline Sale (Tk kg & 160.00 & 160.00 & 160.00 & 160.00 & \multirow{2}{*}{$\mathrm{NS}$} \\
\hline Sale (Tk kg ${ }^{-1}$ broiler) & 152.60 & 166.20 & 171.20 & 179.60 & \multirow{2}{*}{$\mathrm{NS}$} \\
\hline Profit (Tk kg $\mathrm{Tk}^{-1}$ broiler) & $13.60^{\mathrm{c}}$ & $26.60^{\mathrm{b}}$ & $29.70^{\mathrm{b}}$ & $35.10^{\mathrm{a}}$ & $*$ \\
\hline Profit (Tk kg ${ }^{-1}$ broiler) & $20.04^{\mathrm{a}}$ & $21.20^{\mathrm{a}}$ & $19.84^{\mathrm{b}}$ & $17.37^{\mathrm{b}}$ & $* *$ \\
\hline
\end{tabular}

abc, mean values with dissimilar superscripts are significantly different; NS; *, $\mathrm{P}<0.05 ; * *, \mathrm{P}<0.01$. 